Uniwersytet Przyrodniczo-

Humanistyczny w Siedlcach

Siedlce University of Natural

Sciences and Humanities

https://bazawiedzy.uph.edu.pl

\begin{tabular}{|l|l|}
\hline Publikacja / Publication & $\begin{array}{l}\text { Towards comeniology as a science: the scientific and didactical workshop; research } \\
\text { methodology, } \\
\text { Sitarska Barbara }\end{array}$ \\
\hline $\begin{array}{l}\text { Adres publikacji w Repozytorium } \\
\begin{array}{l}\text { RRL / Publication address in } \\
\text { Repository }\end{array}\end{array}$ & https://bazawiedzy.uph.edu.pl/info/article/UPHae324df0e42a480783a96f9d5c83e28d/ \\
\hline $\begin{array}{l}\text { Data opublikowania w Repozytorium / } \\
\text { Deposited in Repository on }\end{array}$ & 22 paź 2021 \\
\hline Rodzaj licencji / Type of licence & Attribution-NoDerivs (CC BY-ND 3.0) \\
\hline Cytuj tę wersję / Cite this version & $\begin{array}{l}\text { Sitarska Barbara: Towards comeniology as a science: the scientific and didactical } \\
\text { workshop; research methodology, Siedleckie Zeszyty Komeniologiczne seria } \\
\text { PEDAGOGIKA, no. 6, 2019, pp. 55-80 }\end{array}$ \\
\hline
\end{tabular}




\title{
TOWARDS COMENIOLOGY AS A SCIENCE - THE SCIENTIFIC AND DIDACTICAL WORKSHOP; RESEARCH METHODOLOGY1
}

\author{
W STRONĘ KOMENIOLOGII JAKO NAUKI - \\ WARSZTAT NAUKOWY I DYDAKTYCZNY; METODOLOGIA BADAŃ
}

DOI: $10.5604 / 01.3001 .0013 .6244$

\begin{abstract}
The article depicts John Amos Comenius' selected ideas and their reference to the contemporary times. It is mainly based on his two major works: Great Didactics and Pampaedia, my own research papers and other available ones, as well as on some research conducted by education science students for their MA theses concerning John Amos Comenius' teacher in reference to the modern teacher ${ }^{2}$. It focuses on Comenius' idea of permanent education, which refers to contemporary education ${ }^{3}$. Nowadays permanent education is a key educational challenge in Poland, Europe and all over the world. The article is an attempt to define comeniology as an emerging scientific discipline and specify the areas and ranges of comeniological research, mentioning its authors and describing their output published in "Siedlce Comeniological Research Bulletin. pedagogy series". I prove the evolutional character of comeniological research. The article also mentions my education science students' interest in Comenius and their activity including the research conducted for their MA theses about Comenius, presentations and written texts intended to be published in "Siedlce Comeniological Research Bulletin, pedagogy series".
\end{abstract}

\footnotetext{
1 The article contains modified contents of part two of another article with a different title, published in Polish in volume 5 of "Siedlce Comeniological Research Bulletin, pedagogy series", See: B. Sitarska, Jan Amos Komeński w trzecim tysiącleciu. Odczytania - kontynuacje - krytyka, In: B. Sitarska (ed.), Jan Amos Komeński w epoce współczesności. Odczytania - kontynuacje krytyka, p. 212-250.

${ }^{2}$ Anna Borychowska, Nauczyciel Jana Amosa Komeńskiego w recepcji współczesnych nauczycieli; Karolina Nowicka, Nauczyciel Jana Amosa Komeńskiego a nauczyciel współczesny, Education Institute, Siedlce University of Natural Sciences and Humanities, Siedlce 2018.

${ }^{3}$ A scientific monograph entitled School education in the context of lifelong education in an autobiographic perspective is being written, based on the idea of permanent education and on some research. It is supposed to be published in 2019 at Siedlce University of Natural Sciences and Humanities.
} 
Keywords: John Amos Comenius, John Amos Comenius' ideas, contemporary educational challenges, pansophia, interdisciplinary character of John Amos Comenius' writings, interdisciplinary comeniological research, evolutional character of comeniological research, comeniology as an emerging scientific discipline, significance of comeniological research

Streszczenie: W artykule przywołuję wybrane idee Jana Amosa Komeńskiego i ich odniesienie do współczesności. Bazuję tutaj głównie na dwóch dziełach uczonego: Wielkiej dydaktyce i Pampaedii, opracowaniach własnych, dostępnych opracowaniach dotyczących twórczości Komeńskiego i badaniach studentek pedagogiki, wykonanych do prac magisterskich, traktujących o nauczycielu Jana Amosa Komeńskiego w odniesieniu do nauczyciela współczesnego 4 . Przywołuję ideę edukacji nieustającej Jana Amosa Komeńskiego, która odnosi się do współczesnej edukacji ${ }^{5}$. Jest ona dzisiaj priorytetowym wyzwaniem edukacyjnym w Polsce, Europie i na świecie. Podejmuję próby definiowania komeniologii jako rodzącej się dyscypliny naukowej i wyszczególniam obszary i zakresy badań komeniologicznych, przywołując ich Autorów i charakteryzując ich twórczość w „Siedleckich Zeszytach Komeniologicznych, seria pedagogika”. Wykazuję ewolucyjny charakter badań komeniologicznych. Nawiązuję również do zainteresowania Komeńskim moich studentów pedagogiki i ich aktywności, przejawiającej się w badaniach do prac magisterskich o J.A. Komeńskim, prezentacjach i tekstach pisanych do „Siedleckich Zeszytów Komeniologicznych, seria pedagogika".

Słowa kluczowe: Jan Amos Komeński, idee Jana Amosa Komeńskiego, współczesne wyzwania edukacyjne, pansofia, interdyscyplinarny charakter twórczości Jana Amosa Komeńskiego, interdyscyplinarne badania komeniologiczne, ewolucyjny charakter badań komeniologicznych, komeniologia jako tworząca się dyscyplina naukowa, znaczenie badań komeniologicznych

\section{Instead of INTRODUCTION - the phenomenon of "immortality" of John Amos Comenius' pedagogical ideas}

John Amos Comenius, a Czech educationist, a Moravian (born 1592 died 1670 in Naarden, the Netherlands), was connected with Poland, mainly Leszno, but also with Toruń, Elbląg, Poznań, Gdańsk, and Wrocław. He lived and worked in Leszno between 1628 and 1642, 1648 and 1650; 1654 and 1656. It is there, in his "homeland in exile", where he was staying due to religious repressions in his own home country, that many of his outstanding works were created.

\footnotetext{
${ }^{4}$ Anna Borychowska, Nauczyciel Jana Amosa Komeńskiego w recepcji współczesnych nauczycieli; Karolina Nowicka, Nauczyciel Jana Amosa Komeńskiego a nauczyciel współczesny, Instytut Edukacji, Uniwersytet Przyrodniczo-Humanistyczny w Siedlcach, 2018.

${ }^{5}$ Based on the idea of permanent education, as well as on appropriate research, a monograph is being written, entitled School education in the context of lifelong learning from an autobiographical perspective. It is going to be published in 2019 at the Siedlce University of Natural Sciences and Humanities.
} 
In all the spheres of his activity, mainly as a citizen of Leszno, he travelled a lot and exchanged loads of letters with scholars from Poland (mainly from Gdańsk, Elbląg, and Toruń) and from other European countries (such as Sweden, England, the Netherlands, Transylvania, Hungary - the town of Sárospatak) ${ }^{6}$. Each country and each town he stayed in is marked by his significant activity and/or a publication of a great work of his. In each place where he stayed, he would preach his own educational ideas and improve his educational concepts.

I have already attempted to interpret John Amos Comenius in the contemporary times before ${ }^{7}$. I based on the most essential facts about his life as well as on his writings and research papers devoted to him which have not been mentioned in "Studia Comeniana Sedlcensia"8 or in "Siedlce Comeniological Research Bulletin, pedagogy series" so far'. I presented and analyzed selected facts about Comenius' life. I emphasized the influence of his childhood and youth on his whole life and writings. I characterized Comenius' writings throughout his life and proved the significance of his output which had appeared during his stay in Poland, mainly in Leszno. In the concatenation of interrelated facts about his life and writings, which account for one another, I observed the phenomenon of "immortality" of his ideas and works. His writ-

\footnotetext{
${ }^{6}$ John Amos Comenius' numerous foreign contacts and correspondence were extensively described by Kamila Szymańska: Kontakty zagraniczne Jana Amosa Komeńskiego (zarys problematyki), In: B. Sitarska (ed.) Jan Amos Komeński - jego pedagogika i filozofia, „Siedlce Comeniological Research Bulletin. pedagogy series", vol. 2, Siedlce University of Natural Sciences and Humanities, Siedlce 2015, p. 227-235.

7I wrote more about John Amos Comenius' life and writings in: B. Sitarska, Jan Amos Komeński $w$ trzecim tysiącleciu. Odczytania - kontynuacje - krytyka, In: B. Sitarska (ed.), Jan Amos Komeński $w$ epoce współczesności, "Siedlce Comeniological Research Bulletin. pedagogy series", vol. 5, Siedlce University of Natural Sciences and Humanities, Siedlce 2018, p. 211-225.

8The scientific series "Studia Comeniana Sedlcensia", edited by Barbara Sitarska and Roman Mnich, appeared between 2007 and 2012 at the Faculty of Humanities of Siedlce University of Natural Sciences and Humanities (Vol. 1 - John Amos Comenius and the culture of Baroque (2007), Vol. 3 - John Amos Comenius in the context of European history and culture of the 17th century (2010); Vol. 4 - John Amos Comenius and the 17th century Europe (2012); Vol. 2 - Werner Korthaase - a researcher of John Amos Comenius, edited by Barbara Sitarska, Roman Mnich and Manfred Richter (2009).

9 The scientific series "Siedlce Comeniological Research Bulletin, pedagogy series", edited by Barbara Sitarska, has been appearing since 2014 as a multi-author monograph (it has an ISBN) and as a magazine (ISSN: 2083-4179; 2450-7245). It is published yearly by Siedlce University Press. So far, the following volumes have appeared: John Amos Comenius and his views of education, vol. 1 (2014); John Amos Comenius - his education science and philosophy, vol. 2 (2015); John Amos Comenius - modern interpretations and reinterpretations of his writings, vol. 3 (2016); Modern perceptions of John Amos Comenius, vol. 4 (2017); John Amos Comenius in the contemporary period - interpretations - continuations - critique, vol. 5 (2018). Since 2018, they have only been published as a scientific magazine.
} 
ings meet the needs of his times, but he was also a visionary who wanted to organize the human matters in the future as well. His genius is that the rules he referred to are accurate in our times, too. They are thought-provoking and invite us to copy them.

Nowadays, Comenius appears as a teacher of Europe, or even a "teacher of the nations". He wanted to "shape a man through education, objective requirements of the knowledge and society, and the development of his/her mind and ability to act for the common good (...), he tried to struggle with the existing social order to enable every child to develop fully and become a human being"10. (...) That is why Comenius, as a "teacher of the nations" is so close to us and our times.

Since time immemorial, we have been trying to get to know, explore, understand and interpret John Amos Comenius' ideas, to recognize the meaning of the heritage of his educational thought in modern Europe, which is seeking its new identity in the process of integration. The universal message of his ideas of education, ahead of their time and breaking the existing religious and cultural barriers, becomes subject to reflection. To what extent are his ideas up-to-date nowadays and can they give rise to new theories being developed in the global civilization of the $21^{\text {st }}$ century ${ }^{11}$

It is astonishing that in the $21^{\text {st }}$ century we discover the vitality of John Amos Comenius' works, philosophy and education science. However, as far as Comenius' ideas are concerned, they are difficult to extract from the entirety developed by the author of "Great Didactics", which is full of ambiguities, and even contradictions. How can you explain, then, the fact that a theologian, a lover of metaphysics deals with education and creates an "art of teaching" with "pansophia" as its core. There are more examples of similar ambiguities, but it is not them that determine Comenius' unique scientific achievements ${ }^{12}$.

John Amos Comenius appreciated the important role of communication in society, he could use the available communication techniques, which helped him gain social recognition and publicity. He was fascinated by the art of printing. "The fact that Comenius' works were so popular can be perceived as

\footnotetext{
10 J.A. Comenius, Wielka dydaktyka, Introduction and note by B. Suchodolski, Wrocław 1956, p. XCVIII.

${ }^{11}$ From the assumptions of the organizers of the conference at the John Amos Comenius State School of Higher Vocational Education in Leszno, Poland, entitled: John Amos Comenius: a teacher of Europe.

12 J. Piaget, Dokąd zmierza edukacja, Warsaw 1948, p. 439; 454; also see: J. Piaget, Jan Amos Komeński (1592-1670), in: Cz. Kupisiewicz, I. Wojnar (eds.): Myśliciele o wychowaniu, vol. 1, Warsaw 1996; see: Cz. Kupisiewicz, Szkice z dziejów dydaktyki, "Impuls" Publishers, Cracow 2010, p. 53-54, 56.
} 
a phenomenon in the history of interpersonal communication where printing was a communications medium," but also his "appropriate" texts responding to particular social needs. He appreciated the role of the mother tongue, the language of the people, understandable language. (Fijałkowski, 2012: 345, 341). John Amos Comenius made a revolution in the way we had understood the different spheres of reality, first and foremost the sphere of education.

As far as Comenius' extra-educational activity is concerned, the following facts are especially worth emphasizing: his striving for the unity of churches; numerous appeals for "world amendment", especially for constant peace; attempts to build international cooperation, which was supposed to be achieved by founding Collegium lucis - an institution functioning as a kind of ministry of education; his demand of the democratization of education, with making education available to girls and the disabled; last but not least, focus on many innovative issues, such as mental development and its stages, psychological foundations of teaching methods, the relationship of the school and other educational institutions, especially the family, and international cooperation concerning the research of education. Realizing the existence of such problems - which still exist nowadays - and continual emphasizing their significance for the future are the reasons for John Amos Comenius' greatest glory.

\section{The scientific workshop, research methodology and their meaning for the development of comeniology and didactics}

A lot of research, discourses, analyses and interpretations have been devoted to John Amos Comenius and his writings in the CONTEMPORARY period. According to the available sources, it can be divided into three stages: the age of NEW EDUCATION - the turn of the $19^{\text {th }}$ to the $20^{\text {th }}$ century; the pedagogy between the two crises (1945-1989); the pedagogy of the turn of the $20^{\text {th }}$ to the $21^{\text {st }}$ century (from 1989 on). My/our comeniological research, all the scientific and research activity as well as organizational activity falls into the last stage, i.e. the $21^{\text {st }}$ century.

Throughout the period, many interdisciplinary discourses of John Amos Comenius, his writings and his educational, theological, writing and political activity have appeared. Contemporary Polish and foreign research papers present the great thinker as an educationist (they interpret his educational works in reference to the modern times, taking into account the vitality of his ideas in the $21^{\text {st }}$ century); a philosopher (a representative of the European 
Baroque philosophy); a theologian (Comenius' ecumenism is vital in the age of modern religious conflicts); and a writer (a representative of the Baroque literature).

All kinds of modern discourses, in all their ranges, focus on the interpretation of Comenius' ideas in modern times. Their main aim is to interpret the contemporary contexts of John Amos Comenius' pedagogy, philosophy and theology through describing detailed issues of interdisciplinary character. They are, among others: analyzing the matter of lifelong education, and the related concept of man's self-cognition at every stage of his/her life/school (stages of life are attributed to schools), (Sitarska, 2015: 145-156; Sitarska, 2018: 227-243) and interpreting the history of perception in history, literature, and the Polish culture. The final effect has been the reinterpretation of John Amos Comenius' educational thought and the reinterpretation of his texts as the Baroque literature.

These tasks make the discussion of Comenius and his writings easier at international conferences, which are mainly held in Poland, the Czech Republic, Holland, and Germany. The aftermath of the research is compact publications and articles about John Amos Comenius based on the analysis and interpretation of his own works and research papers written throughout the centuries, mainly contemporary ones. Volume 3 of "Siedlce Comeniological Research Bulletin, pedagogy series" is devoted to modern interpretations and reinterpretations of Comenius' writings. The texts collected in this volume are interdisciplinary. Their authors are scholars studying different disciplines, frequently many disciplines at the same time. Their interests are often settled at the border between two disciplines: education science and philosophy, education science and art, education science and music, education science and theology. This difficult task has also been undertaken by a historian of education, a social educationist, a special needs educationist, a philosopher and a German teacher ${ }^{13}$.

Such a great variety of the interpretations and reinterpretations of Comenius' rich output enriches our own scientific workshop of comeniology, a new emerging academic discipline, which has not been defined in encyclopedias yet, or placed in the system of sciences. It cannot be a subdiscipline of education science, or another branch of science, as its range goes far beyond

\footnotetext{
13 You can study the interdisciplinary texts of Volume 3 of "Siedlce Comeniological Research Bulletin, pedagogy series" at the website www.comenius.uph.edu.pland/orin: Barbara Sitarska (ed.), Jan Amos Komeński - współczesne interpretacje i reinterpretacje jego twórczości, "Siedlce Comeniological Research Bulletin, pedagogy series" vol. 3, Siedlce University of Natural Sciences and Humanities, Siedlce 2016.
} 
education science in terms of its interdisciplinary character, and is narrow at the same time as its "resources"/ theoretical, empirical and practical scopes

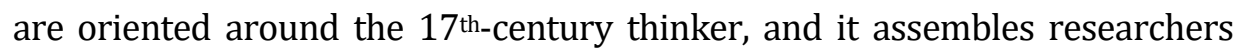
who concentrate on this figure and his output from all over the world, regardless the nationality or religion (atheists also interpret his writings and try to reinterpret his ideas, as in fact he was both a religious and an absolutely secular thinker). I suggest comeniology should be a separate discipline in the area of humanities and social sciences.

Because comeniology deals with man and his never-ending education, which Comenius calls lifelong education or permanent education ("the whole life is school"). As a concept, it fits in the current of contemporary research and is a priority in modern education in Poland, Europe and all over the world. Comenius' school is of both institutional and extra-institutional, symbolic character. However, in all the types of schools, at every stage, education is equally important for a person's development, and its scale, responsibility and level of difficulty are even larger in the symbolic, extra-institutional school.

The educationist paid great attention to religious education, as well as qualifications and knowledge, as "knowledge is the light and remedy for all the evil".

According to Comenius, man is an intermediate between the Creator and the creatures, a reflection of his Creator [...], a small world and a small God, and he should expect happiness from himself, not from external things.(Comenius, 1996: 18, 144). He strongly believed that knowledge and education would make the world better and full of happiness. Comenius tried to convince everyone that Man can be shaped by his own work on himself. The only and best material for shaping a true, genuinely human man is knowledge. This overwhelming knowledge, full and perfect, should be transmitted to people through a universal school for everyone. That is why the school should become a common good for the whole mankind.

All your life, throughout the consecutive "schools of life", you should strive to learn about yourself in order to be able to achieve success, happiness and perfection. The way to these objectives goes through hard creative work on yourself and on your own development. Contemporary man strives to achieve the same goals, also basing on self-cognition, which appears to be the most difficult task. With all his philosophy and educational axiology, Comenius turned to earthly life. In all the areas of his varied activity, Comenius tried to embrace man as a whole with all his temporal fields of activity. He was also 
concerned with a man who is continually a "learner" at "life school", to whom he recommended continuous learning "without limits" (Comenius, 1973: chapters VIII-XVI). To learn continuously means to make the main use of your life.

The emerging comeniology already has reliable foundations as a science. There is much chance of it being formally acknowledged as a science, because Comenius and his OUTPUT are experiencing a renaissance in the $21^{\text {st }}$ century. In Polish and international publications, more researchers of Comenius are appearing. University students also get interested in this figure and not only do they want to learn about his life and writings but they also conduct research, both qualitative (analysis of works by Comenius and about Comenius) and quantitative (surveys of the perception of Comenius' educational concepts, mainly concerning the teacher and teaching principles). They also have their text published in "Siedlce Comeniological Research Bulletin, pedagogy series".

For the first time, I tried to define comeniology in volume 2 of "Siedlce Comeniological Research Bulletin, pedagogy series" entitled John Amos Comenius - his education science and philosophy, in the text John Amos Comenius and the beginnings of comeniology in Polish, English and German. Among other things, I wrote: "For the use of this essay, I looked up the definition of comeniology as a science in encyclopedias and available writings. I did not succeed, however, although all the participants of international conferences, seminars and symposia as well as authors of publications use this term. It undoubtedly seems to be a branch of science, which is developing in every country, first of all in the countries where Comenius stayed, acted and created. As a result, there is a Czech comeniology, as well as Slovak, Polish, Dutch, Hungarian etc. The term of European or even worldwide comeniology is also in use. It is undoubtedly the branch of science whose focus is Comenius' life, educational and political activity and his writings, mainly educational, but also his teachers, colleagues, friends, and students. It is also based on the research conducted by researchers of Comenius and the analyses of their writings about him. It is developing thanks to quality and heuristic research, and remains interdisciplinary and dynamic" (Sitarska, 2015: 36).

In Bohemia, the motherland of the Great Educationist, the anniversary year of Comenius 1882 was recorded in the publications as the beginning of the Czech comeniology. In Poland, comeniology emerged in 1834, when the 19th-century weekly Przyjaciel Ludu (People's Friend) was first issued in Leszno, with the article by Józef Andrzej Łukasiewicz entitled "John Amos 
Comenius, a former head teacher of the Leszno school" about his biography and writings. "It started the large-scale development of the rising Polish comeniology", as Alojzy Konior writes in his book "Jan Amos Komeński i bracia czescy w 380. rocznicę przybycia do Leszna" (John Amos Comenius and the Czech Brethren 380 years after their arrival in Leszno) (1628-2008) (Konior, 2009: 41). In 1847, "Mała Encyklopedia Polska" (Small Polish Encyclopedia) was published in Leszno. It contained a biographic entry on Comenius. In Leszno Biographical Dictionary (2004), a biographical entry on Comenius by Alojzy Konior was included.The Leszno comeniologist'swhole life isconcentrated on John Amos Comenius, his life and output, as well as on related activities, mainly organizing comeniological conferences and seminars of national and international range, and thematic publications.

A significant Polish comeniologist is also the late Tadeusz Bieńkowski, whose writings and comeniological activity contributed a lot to the development of the Polish and European comeniology. He cooperated with Marta Bečkova and Dagmara Čapkova from the Czech Republic. I wrote more about the beginnings and development of the Siedlce, Polish and European comeniology in volume 2 of Siedlce Comeniological Research Bulletin, pedagogy series" entitled John Amos Comenius - his education science and philosophy (Sitarska, 2015; 23-90; in Polish, English and German). One of the modern researchers of John Amos Comenius is Adam Fijałkowski, quoted many times here, the author of the postdoctoral dissertation "Tradition and novelty in Orbis sensualium pictus by John Amos Comenius" (2012) ${ }^{14}$. Its publication was preceded by many years' research and studying reference literature at university libraries in Poland and abroad. Adam Fijałkowski is Tadeusz Bieńkowski's student. His scientific workshop is a perfect base for modern researchers of Comenius and authors of comeniological research papers.

"Siedlce Comeniological Research Bulletin, pedagogy series" presents the results of analytical and interpretational research conducted by scholars, mainly educationists, but also philologists and philosophers, who have already established their positions in the comeniological research. Each of the authors is an expert in their own branch of science. Therefore, it is possible to distinct the areas/ranges/branches of comeniology.

Sławomir Sztobryn carried out a profound analysis of the 20th-century Polish perception of John Amos Comenius in volume 4 of "Siedlce Comeniological Research Bulletin, pedagogy series" (Sztobryn, 2017: 57-72). His comeniological research mainly focuses on pansophia, a branch which is

\footnotetext{
14 The publication appeared within a postdoctoral research project.
} 
studied by almost everyone, but remains unplumbed, and abstract, therefore distant for many researchers and readers. Sławomir Sztobryn is making pansophia more and more understandable. According to this educationistpracticing historical and philosophical education science, a researcher - among others - of John Amos Comenius, pansophia appears in Comenius in two forms. Firstly, in the substantive layer, it constitutes the deepest core, the structural kingpinof the whole of his intellectual output. Secondly, in the formal layer, it is a part of the great 7-volume work ${ }^{15}$. The analyses of Comenius' pansophia, deepened by Sławomir Sztobryn, suggest some ambiguities of the thinker Comenius: the fact that the whole of ideas and its printed part have the same title is misleading (Sztobryn, p. 27). Sławomir Sztobryn carried out an analysis of Comenius' texts, showed its modern interpretations and comments; emphasized the single-sidedness of this idea and its ambiguities. At the same time, he attracted the modern reader's interest in it, enriched our knowledge to the extent which enables us to undertake further research in the area, and also its analyses and interpretations.

The ways other authors of "Siedlce Comeniological Research Bulletin, pedagogy series" perceive Comenius show thatthey treat pansophia as "a basic philosophical category of his system" (see Sroczyński, 2016: 44-45). Wojciech Sroczyński, a social educationist and a poet, described his perception of Comenius as a theologian, educationist, and a politician.

I approve Heliodor Muszyński's idea that John Amos Comenius is a phenomenon of the human mind in several dimensions at the same time. The educationist has been dealing with Comenius as far as research and publishing activity are concerned for a few years, since he got a job at the John Amos Comenius State School of Higher Vocational Education in Leszno, the town of Comenius. It is there that he created the Education ScienceInstitute, which he was the director of, and which had a Comeniological Laboratory. He was also one of the founders of a similar Laboratory at the University of Uman, Ukraine ${ }^{16}$. He had started his studies of John Amos Comenius by having

\footnotetext{
15 Titles of the volumes were specified in Latin and Polish by S. Sztobryn, ibidem.

16 Prof. Inna Osadchenko, PhD of education studies, director of the Polish-Ukrainian J.A. Comenius scientific and research Psychodidactics Laboratory of the Pavel Tychyna State University of Uman (Ukraine), cooperates with the Siedlce comeniological center and "Siedlce Comeniological Research Bulletin, pedagogy series", where she has her texts published, as well as motivates her own colleagues to undertake similar activities.

See: Inna Osadchenko, Psychodidactic ideas of J.A. Comenius: from the history up to the present / Психодидактичні ідеї Я.А. Коменського: від історії до сьогоденн, In: B. Sitarska (ed.) Wspótczesne recepcje Jana Amosa Komeńskiego, "Siedlce Comeniological Research Bulletin, pedagogy series", vol. 4, Siedlce University of Natural Sciences and Humanities, Siedlce 2017, p. 207-226.
} 
a few dissertations of his educational activity published. First of all, he has provided the methodological foundations of John Amos Comenius' writings (Muszyński, 2014: 93-118) and enriched the knowledge of his intellectual workshop, as well as developed the concept of Comenius' school in interdisciplinary terms. (Muszyński, ibidem: 101-128).

Janina Florczykiewicz, an educationist working at the border between education science and art, enriched the comeniological knowledge with her discussion of the ways leading to the knowledge of man and the surrounding world in John Amos Comenius' writings and an analysis and interpretation of the thinker's pedagogical thought. (Florczykiewicz, 2017: 73-82). Comenius' conviction of man's privileged position in the world is reflected by his belief in unlimited abilities of the human mind as far as building knowledge is concerned. The brilliancy of human mind, treated as a potency, only suggests a possibility (a deposit), which will not develop by itself, that is why a key factor of a man's development, according to Comenius, is the process of education. He treats it as preparation for the accomplishment of human potencies by showing the methods and teaching how to use them in life. For Comenius, education is the objective of upbringing as well as a man-constituting value. In his opinion, it embraces the whole of knowledge shaped as a result of upbringing. (Florczykiewicz, 2016: 53-62).

Andrzej Borkowski, a literary scholar and a Slavist, has been involved in our comeniological activity from the beginning. His publications are oriented around the symbols and symbolism in John Amos Comenius' writings. They are: the labyrinth, the light, the way, the fountain, the gate and many more, not analyzed yet. "Through these cultural signs, Comenius builds a positive concept of man and the world, based on Christian foundations, rooted in the Bible, the mental power, and the book of the nature". (Borkowski, 2012: 244). "John Amos Comenius sought means of expression to let him reflect the spiritual anxiety of the epoch. (...) Andrzej Borkowski uses the ambiguity and vividness of these symbols to attract the reader's attention to the ideas of community, peace, religious dialogue and the need of lifelong education". (Borkowski, 2017: 105). According to Borkowski, it is thanks to the symbolism, among others, that Comenius' works are so splendid and interesting to the modern reader. They keep him in suspense, intellectual anxiety, and arouse much curiosity, and even admiration. These may contribute to his "immortality" as well. Comenius had a great writing talent, he wrote beautifully, brilliantly, and he could communicate with the reader. 
In his educational works, Comenius emphasized the idea of teaching everyone everything about everything, therefore he insisted on educating girls/women as well as boys/men, the disabled as well as the able-bodied, as the body often compensates for a worse ability or a complete lack of it in one part with an improved ability of another. Nowadays, we fully stick to those postulates."Siedlce Comeniological Research Bulletin, pedagogy series" present text concerning this issue. Leszek Ploch, a special needs educationist and a musician interested in John Amos Comenius' ideas, presented his idea of disabled people's education for creative activity (Ploch, 2015: 165-190) in volumes 2 and 4, and developed it in the text The gift of the spiritual value in the course of life of disabled students in the interpretation of John Amos Comenius' ideas (Ploch, 2017: 83-104), quite an original title.

Barbara Grzegorczyk analyses various issues in the Bulletin. They are: John Amos Comenius' teacher and learner, communication in education in John Amos Comenius' writings, mathematical sciences in John Amos Comenius' concept, and the value of the book in human life. Her papers have philosophical foundations, and mainly didactical/methodological advantages ${ }^{17}$.

A strictly didactic subject matter, concerning John Amos Comenius' didactics and school, his didactic rules and the natural method of teaching, was analyzed in the first volumes of the Bulletin by Kazimierz Żegnałek (Żegnałek, 2014: 63-92) and Grażyna Dzida. The latter author additionally analyzed natural sciences education according to John Amos Comenius' idea (Dzida, 2015: 207-2014). Pre-school education in John Amos Comenius' philosophy was analyzed by Anna Klim-Klimaszewska and Ewa Jagiełło in volume 1 of "Siedlce Comeniological Research Bulletin, pedagogy series" (Klimaszewska, Jagiełło, 2014: 175-188).

Kamila Szymańska has been cooperating with us from the beginning of our comeniological activity. She writes about historical matters, connected with John Amos Comenius' scientific journeys and exchange of letters, as well as with Leszno, the town of Comenius, and its schools (Szymańska, 2017: 141-145; Szymańska, www.comenius.uph.edu.pl: vol 1, 2, 3). Her texts are based on rich source materials collected in the Leszno Museum and at scientific libraries, mainly in Poznań and Leszno. The throughout comeniological studies results in texts which are rich in content. The subject is completed by Adam Podsiadły (Podsiadły: 2015: 237-246).

\footnotetext{
17 See this author's texts in vol. 1, 2 and 4 of "Siedlce Comeniological Research Bulletin, pedagogy series" or at the website www.comenius.uph.edu.pl.
} 
John Amos Comenius' man as a free user of the world is the subject of Cezary Kalita's philosophical treatise (Kalita, 2017: 63-70).The author emphasizes that it is "an element of Comenius' broader view of social and political reality consistent with his neo-Platonic philosophy". The thinker was certain that common liberation of mankind could only take place through education. In order to achieve this, however, religious and political freedom is needed, as well as learning freedom, as Bacon postulated. (Kalita, 2016: 63-70).

Renata Matysiuk analyzed the right to learn depicted by Comenius in volume 4 of "Siedlce Comeniological Research Bulletin, pedagogy series" (Matysiuk, 2017: 127-140), emphasizing how up-to-date this idea was. She highlighted Comenius' idea that upbringing and education is a great strength, which is able to rebuild the world. In volume 3 of the Bulletin, the author turned to the subject of man's safety as a universal value in Comenius' depiction. (Matysiuk, 2016: 103-114).

Barbara Sitarska, the editor-in-chief of "Siedlce Comeniological Research Bulletin, pedagogy series", describes various topics in pedagogical and philosophical depiction. They are mostly her own perceptions of Comenius and different areas of his writings. She has had texts about Comenius' ideas/concepts published, also in German, English and Russian ${ }^{18}$. The author first undertook comeniological research in 2007, and together with Roman Mnich organized international seminars attended by Polish and European researchers of Comenius: German, Czech, Slovak, Russian, and Ukrainian (between 2007 and 2012). Their cooperation resulted in publishing a four-volume series "Studia Comeniana Sedlcensia'19. The activity had been inspired by previous contacts (meetings and correspondence) with Werner Korthaase from Berlin, a honorable chairman of the German Comeniological Society/ Deutschen Comenius-Gesellschaft'20. On the basis of "Siedlce Comeniological Research Bulletin, pedagogy series" edited by Barbara Sitarska (education science) and the second series edited by Roman Mnich (philology and history

\footnotetext{
18 B. Sitarska, see the publications in the four volumes of "Siedlce Comeniological Research Bulletin, pedagogy series", and also at the website www.comenius.uph.edu.pl.

${ }^{19}$ See the titles and contents of the volumes at www.comenius.uph.edu.pl_or reach directly to the volumes of the series, quoted here many times.

20 The history of our comeniological activity was described in more detail in volume 2 of "Siedlce Comeniological Research Bulletin, pedagogy series", in the text: O Janie Amosie Komeńskim i poczatkach komeniologii (in Polish, English and German), op. cit., p. 23-90. Volume 2 of "Studia Comeniana Sedlcensia" (2009) was devoted to Werner Korthaase. In 2018, we commemorated his 10th death anniversary. The latest volume contains a text by Manfred Richter about this comeniologist and his contribution to the development of the German and European comeniology.
} 
- not printed yet), Encyclopedic Lexicon of John Amos Comenius was about to be developed. That extremely ambitious and difficult project has not been accomplished yet ${ }^{21}$.

There are many authors who have written just one text, or researchers who probably have not specified their objectives or ranges of research yet, so their texts are oriented around different topics. Volume 4 presents Polish perceptions of John Amos Comenius as well as Czech, German, Ukrainian, Slovak, Slovenian, Bosnian, and Serbian. Volume 5 continues this cooperation. The foreign authors have specified their research ranges of education science, theology, ecumenism (Manfred Richter, Germany), Comenius' educational ideas and their reflection in today's European education (Bernhard Stalla, Germany), modern perceptions of Comenius ideas in the Czech Republic (Lubomír Hampl, the Czech Republic), John Amos Comenius' psychopedagogical ideas, their interpretation and continuation in modern times (Inna Osadchenko with her team, Ukraine), John Amos Comenius' contribution to the development of didactic methodology (Jelena Maksimović with her team, Serbia). The above texts, as well as others by foreign authors (Karel Rýdl, JánHabl (the Czech Republic), Majda Cencić (Slovenia), Maria Kultajeva, Svetlana O. Ganaba, Natalia V. Bakhmat (Ukraine), Muhamed Škrgić (Bosnia and Herzegovina) can be found in volume 4 of "Siedlce Comeniological Research Bulletin, pedagogy series" (2017), as well as in the latest volume. They are also available at the website www.comenius.uph.edu.pl.

It is difficult to state now who will be acknowledged to be the forerunner/s of the Polish comeniology in the literature and encyclopedias. Now that the latest volume is being prepared it is not known where and when it will take place.

\section{The research presented here appears to mainly contribute to the development of:}

- the Polish comeniology, as an emerging branch of knowledge, in its ideological, historical, and educational aspects;

- modern didactics as a sub-discipline of education science;

- modern theological and scholiological discussion of the school as an educational institution and of the methodology of teaching and learning.

\footnotetext{
${ }^{21}$ These comeniological projects are described at the website, mentioned here many times.
} 


\section{The comeniological research also contributes to:}

- the implementation of Comenius' didactic views in the modern context (mainly the didactic rules);

- the description of the history of perception of John Amos Comenius and his writings in Poland.

The publications by the Siedlce comeniological centre have attempted: to prove in an empiric way the "immortality" of John Amos Comenus' idea of permanent education; to use John Amos Comenius' idea of permanent education in the modern idea of lifelong learning; to integrate comeniologists in Europe through conducting all-European research. These attempts have contributed to the renaissance of John Amos Comenius' ideas, utopian in the $17^{\text {th }}$ century, and apparently real in the $21^{\text {st }}$ century. Moreover, the publications and seminars have often presented Comenius as a great humanist of the European Baroque 22 .

The basis of the scientific workshop has been interdisciplinary analyses and interpretations of source materials, Comenius' works and works about Comenius. The problems stated have been solved through qualitative research (text analyses), quantitative research, statistical research (analyses of surveys of Comenius, his educational and didactical ideas and his idea of the teacher in reference to modern teachers [comparative and perceptive research]). It has mainly manifested and will manifest itself in:

- hermeneutic interpretations of Comenius' writing;

- students' group discussions of the reality of Comenius' assumptions of school education and permanent education;

- making students aware of the fact that the idea of learning and education according to Comenius' rules and methods has a real chance to come true in the $21^{\text {st }}$ century;

- making students aware of the fact that the school is a very broad concept and it comprises not only the school as an educational institution but also the remaining periods of man's life outside it.

We have based on the assumptions of pedagogical hermeneutics. Pedagogy as a humanistic science (science of the spirit) is based on anthropologic-epistemological assumptions, i.e. concerning the human being in the way he is (existential aspect), and in the way he gets to know the world, himself and

\footnotetext{
22 The first thorough analyses of our comeniological research appeared in 2011 while preparing an international pedagogic-philosophical ministerial group project Comenius yesterday, today, and tomorrow in cooperation with the German, Czech and Slovak. The project was rejected due to formal reasons. It was not aimed at academic teachers.
} 
himself in the world (the threefold understanding of hermeneutics). It is "a process and a research approach at the same time, which occurs besides the process of explanation, which is characteristic of sciences of the spirit, and the way of philosophical cognition. It is a methodological aspect grounded in a specific epistemology" (Ablewicz, 1998: 31). Modern hermeneutics should be also understood as "a method of interpretation of a broadly understood text (...), in which (...) the structure of a hermeneutic spiral can be seen, and seeking the meaning consists in a mutual harmony of the parts and the whole" (Ablewicz, ibidem).

In pedagogy understood like this, as a humanistic science, besides the matter or understanding man as a physical and biological being, there is spirit that determines the humanity. The point is the cultural survival of man.

The hermeneutic sphere is first of all a sphere of symbols, values, and obligations. It is there that a human being crystallizes his vocation, answering the question Who should I be? It can be comprised in four extents: i/ of texts, ii/ of the history, iii/ of the educational reality, iv/ of the interpretation in empirical research. According to hermeneutic pedagogy, it is not the method that makes the difference but it is the area, the research subject, which is the reality we are interested in ${ }^{23}$. Here we deal with the 17 th-century, Baroque reality, presented in John Amos Comenius' works, concerning his ideas accomplished throughout the human life, at all its stages/ schools according to the principle the whole life is school. The research of Comenius comprises all these areas. The anthropological depiction should also be included here, which presents man as a bodily-psycho-spiritual unity. Such a view of the comeniological research requires throughout study of hermeneutics and anthropology, and reanalysis and reinterpretation of Comenius' works and works about Comenius in this depiction.

The study of Comenius' pansophia in this depiction was already undertaken by Sławomir Sztobryn. He analyzed and interpreted the depiction of pansophia by its creator as a "holistic, harmonious program of reaching full humanity by man. Pansophia was supposed to manifest itself in three areas: art, nature, and divinity. It was an expression of the conviction that despite its diversification, in the cognizable world there are unchangeable rules, which are common and rare at the same time. John Amos Comenius' assumption was

\footnotetext{
${ }^{23}$ Mainly based on the text by Krystyna Ablewicz: Hermeneutyka i fenomenologia $w$ badaniach pedagogicznych, In: S. Palka (ed.), Orientacje $w$ metodologii badań pedagogicznych, Jagiellonian University Press, Cracow 1998, 1st edition, p. 25-42. and on the works by Roman Ingarden: Książeczka o człowieku, Wydawnictwo literackie, Cracow 1998, 2003 and R. Ingarden, Dążenia fenomenologów, In: Z badań nad filozofia współczesną, PWN, Warsaw 1963.
} 
to come true providing that its four conditions were met (...): a new language, new books, new schools and a new council". (Sztobryn, 2016: 25). In principle, the idea of pansophia was universal.(Sztobryn, 2016: 25-34).

Attempts of such a depiction of Comenius' works were made by Jan Hábl from the Czech Republic in volume 4 of "Siedlce Comeniological Research Bulletin, pedagogy series" (Habl, 2017: 199-206). The author analyzes the anthropological aspects in John Amos Comenius' early works. He presents the dynamic development of his concept of humanity. Moreover, he tries to prove that Comenius' specific concept of resignation typical of his works after the age of Biała Góra has an exceptionally positive meaning, therefore it is an important foundation for his educational and corrective plans and aspirations in the following stages of his life and writing activity. His ideas throughout his life were quite dynamic. Jan Hábl presented the development of Comenius' anthropology in the early stages of his life and work. He tried to explain "how the external factors in Comenius' life influenced the hesitations in his understanding of man, and the consequences of this understanding for the future educational and corrective projects, which turned out to be so perfect and important for the European cultural heritage" (Hábl, 2017: 199).

An academic teacher plays three integrated functions: didactic, scientific research, and the function of a role model for the students. Analyzing his/her functions, he/she naturally adopts the role of a reflexive researcher of their own educational practice, and establishes their own priorities in this field, then he/she analyzes what results they bring for themselves and their students. This reflection concerning the academic teacher as a researcher of his/her own educational practice has appeared in my writings many times, taking into account the directions of my research and my own methodological workshop. (Sitarska, 2008: 185-198). Among the directions of my research, or my research areas, the research of John Amos Comenius appeared in 2007.

For the second time, I made my research directions the subject of such a reflection in 2016. (Sitarska, 2016: 251-272). It is then that I made Cempel's idea the motto of my paper: Knowledge in any place and at any time, as knowledge can be gained always and everywhere; it is permanent and interdisciplinary. Gaining knowledge is no longer only associated with the school and young people, but with every place where we are and every stage of our lives. This idea inspires both teachers and learners/students. As a result, the dimension and models of scientific research, including educational research, have changed. Quantitative or qualitative research only is not enough. Best results can be obtained with the combination of these two models. Among the 
specified directions of research, the research of John Amos Comenius also appeared. Emphasizing the significance of the research, I stressed the fact that it was Comenius, as one of the forerunners of permanent education, that had inspired me to conduct research of lifelong learning by people of different age groups. The result of the research conducted was an International Seminar of Comenius, ${ }^{24}$ the idea of an Encyclopedic Lexicon of John Amos Comenius (in the future), and currently the concept of "Siedlce Comeniological Research Bulletin., pedagogy series", and a project of an individual monograph School education in the context of permanent education in an autobiographical perspective ${ }^{25}$. In order to remain in accordance with my functions of an academic teacher, I have made my students interested in Comenius' didactic system, as well as in the research of the modern perception of Comenius, his teacher and didactic principles.

\section{Conclusion}

We are getting more and more familiar with John Amos Comenius. There seems to be nothing more to do in this area, but it is not true. There is a lot more to do in almost every European country and language. Nowadays, both in Poland and Europe, as well as outside it, we can observe a renaissance of Comenius and his groundbreaking ideas ${ }^{26}$. In the $21^{\text {st }}$ century, his rich output is not completely clear yet and still arouses many controversies. In his synthetic summary of the output of the German comeniological research, the modern German scholar Heinz- Elmar Tenorth states that Comenius is "a frequent subject of research yet he remains unknown"27.

Modern comeniologists are going to analyze and interpret his writings for many years to come, and it seems that they still will not have had enough

\footnotetext{
24 See: Jan Amos Komeński a kultura epoki baroku edited by B. Sitarska and R. Mnich, „Studia Comeniana Sedlcensia", Volume 1, Akademia Podlaska Press, Siedlce, 2007.

25 O Janie Amosie Komeńskim i jego poglądach na edukację/John Amos Comenius and his views of education / Über Johann Amos Comenius und seine AnsichtenzurBildung, "Siedlce Comeniological Research Bulletin, pedagogy series", Siedlce University of Natural Sciences and Humanities, Siedlce 2014; B. Sitarska (ed.) Jan Amos Komeński - jego pedagogika i filozofia / John Amos Comenius- his education science and philosophy/Johann Amos Comenius- seine Pädagogik und Philosophie, "Siedlce Comeniological Research Bulletin, pedagogy series", vol. 2, Siedlce University of Natural Sciences and Humanities, Siedlce 2015.

26 It is proved by international seminars and conferences of John Amos Comenius held in the Czech Republic (Prague), Holland (Naarden); Germany (Alfter near Bonn), and Poland (Leszno, Siedlce). They have been attended by comeniologists from all over Europe and Japan, including myself. I mean the events that have taken place since 2007 till the present.

27 I am quoting A. Fijałkowski, Tradycja i nowatorstwo..., op. cit., p. 24.
} 
of them and they will see the incompleteness and "empty spaces" in their interpretations/perceptions. The research conducted so far in modern comeniological centres suggests so. As Stanisław Sztobryn points out, there are other reasons as well: the lack of full edition of source materials, the world's great perception of Comenius' output, the changing significance of Comenius for the modern times. According to Sztobryn, Comenius combines two features which are important nowadays as well: "he is a regional spirit (a connection with religion and the Czech Brethren's Dispersion), as well as a universal spirit, a European carrying his universal or even utopian message for posterity: the idea of democracy, empowerment, enlightenment, and common happiness". (Sztobryn, 2017: 65).

In the literature, John Amos Comenius has been acknowledged to be the greatest and most famous representative of the 17th-century pansophism (Fattori, 1974: 99-102; Kvačala, 1892:Schaller, 1962; Vasoli,1996:22)28.

\section{Bibliography}

Ablewicz Krystyna: Hermeneutyka i fenomenologia $w$ badaniach pedagogicznych, In: S. Palka (ed.), Orientacje w metodologii badań pedagogicznych, Cracow 1998, 1st edition, p. 25-42.

Bieńkowski Tadeusz, Jan Amos Komeński o nauczaniu i wychowaniu, Pułtusk 2000.

Bieńkowski Tadeusz, Komeński dzisiaj - kilka refleksji własnych, In: B. Sitarska, R. Mnich (eds.), Jan Amos Komeński a Europa XVII wieku, „Studia Comeniana Sedlcensia", vol. 4, Siedlce 2012, p. 335-337.

Borkowski Andrzej, Poznawcze i dydaktyczne funkcje symboli $w$ dziełach Jana Amosa Komeńskiego, In: B. Sitarska, R. Mnich (eds.), Jan Amos Komeński a Europa XVII wieku, „Studia Comeniana Sedlcensia”, vol. 4, Siedlce 2012, p. 235- 244.

Borkowski Andrzej, Wieża Babel i labirynt - o symbolicznych unaocznieniach podroży w dziełach Jana Amosa Komeńskiego w kontekście kultury barokowej, In: B. Sitarska (ed.) Współczesne recepcje Jana Amosa Komeńskiego, "Siedlce Comeniological Research Bulletin, pedagogy series", vol. 4, Siedlce 2017, p. 105-114.

Borychowska Anna Agnieszka, Jan Amos Komeński - jego życie i twórczość recepcja studentki pedagogiki, In: B. Sitarska (ed.) Wspótczesne recepcje

\footnotetext{
28 The bibliography of works concerning J.A. Comenius is presented by Cesare Vasoli in: Encyklopedyzm w XVII wieku, Polish Academy of Sciences, Philosophy and Sociology Institute, Warsaw 1966, p. 22.
} 
Jana Amosa Komeńskiego, "Siedlce Comeniological Research Bulletin, pedagogy series", vol. 4, Siedlce 2017, p. 155-164.

Cempel Czesław, Nowoczesne zagadnienia metodologii i filozofii badań, Exploitation Technology Institute, Radom 2005.

Demolition of Leszno (Lesnae exicidum) in April 1656 was described by Comenius with historical accuracy. In: A. Konior (ed.), Jan Amos Komeński $i$ bracia czescy $w$ 380. rocznice przybycia do Leszna (1628-2008), Leszno 2009.

Dymek Karolina, Koncepcja edukacji nieustającej Jana Amosa Komeńskiego, In: B. Sitarska (ed.) Jan Amos Komeński - jego pedagogika i filozofia, "Siedlce Comeniological Research Bulletin, pedagogy series", vol. 2, Siedlce 2015, p. 157-164.

Dzida Grażyna, Edukacja człowieka w zakresie nauk przyrodniczych i ścisłych według koncepcji Jana Amosa Komeńskiego, In: B. Sitarska (ed.) Jan Amos Komeński - jego pedagogika i filozofia, "Siedlce Comeniological Research Bulletin, pedagogy series", vol. 2, Siedlce 2015, p. 207-214.

Fijałkowski Adam, Orbis pictus - Świat malowany Jana Amosa Komeńskiego, Warsaw 2008.

Fijałkowski Adam, Tradycja i nowatorstwo w „Orbis sensualium pictus” Jana Amosa Komeńskiego, Warsaw 2012.

Florczykiewicz Janina, Drogi prowadzqce do wiedzy o człowieku i otaczajq̨cego go świata w twórczości Jana Amosa Komeńskiego, In: B. Sitarska (ed.), Jan Amos Komeński - współczesne interpretacje i reinterpretacje jego twórczości, "Siedlce Comeniological Research Bulletin, pedagogy series", vol. 3, Siedlce 2016, p. 53-62.

Florczykiewicz Janina, Myśl pedagogiczna Jana Amosa Komeńskiego, In: B. Sitarska (ed.), Współczesne recepcje Jana Amosa Komeńskiego, "Siedlce Comeniological Research Bulletin, pedagogy series", vol. 4, Siedlce 2017, p. 73-82.

Hábl Jan, Development of anthropological accents in Comenius' early work and its implications for his philosophy of education, In: B. Sitarska (ed.), Współczesne recepcje Jana Amosa Komeńskiego, "Siedlce Comeniological Research Bulletin, pedagogy series", vol. 4, Siedlce 2017, p. 199-206.

Hampl Lubomír, Współczesna recepcja myśli Komeńskiego w Czechach na podstawie przykładu jego słynnej sentencji, dotyczacej narodu i wizji lepszej przyszłości, In: B. Sitarska (ed.), Współczesne recepcje Jana Amosa Komeńskiego, "Siedlce Comeniological Research Bulletin, pedagogy series", vol. 4, Siedlce 2017, p. 179-190.

Ingarden Roman, Dążenia fenomenologów, In: Z badań nad filozofia współczesnq, Warsaw 1963.

Ingarden Roman: Książeczka o człowieku, Cracow 1998; 2003. 
Jarczykowa Mariola, Czas wolny dzieci młodzieży w poglądach Jana Amosa Komeńskiego, In: B. Sitarska (ed.) Jan Amos Komeński - jego pedagogika i filozofia, "Siedlce Comeniological Research Bulletin, pedagogy series", vol. 1, Siedlce 2015, p. 191-198.

Jarczykowa Mariola, Jan Amos Komeński jako przewodnik życia młodzieży, In: B. Sitarska (ed.), O Janie Amosie Komeńskim i jego poglądach na edukację, "Siedlce Comeniological Research Bulletin, pedagogy series", vol. 1, Siedlce 2014, p. 227-238.

Kalita Cezary, Jana Amosa Komeńskiego człowiek jako „wolny użytkownik świata", In: B. Sitarska (ed.), Jan Amos Komeński - współczesne interpretacje i reinterpretacje jego twórczości, "Siedlce Comeniological Research Bulletin, pedagogy series", vol. 3, Siedlce 2016, p. 63-70.

Klim-Klimaszewska Anna, Jagiełło Ewa, Edukacja przedszkolna w koncepcji Jana Amosa Komeńskiego, In: B. Sitarska (ed.), O Janie Amosie Komeńskim i jego poglądach na edukację, "Siedlce Comeniological Research Bulletin, pedagogy series", vol. 1, Siedlce 2014, p. 175-188.

Komenský Jan Ámos, In: Wielkie biografie, vol. 1, Przywódcy, reformatorzy, myśliciele, Warsaw 2007.

Komeński Jan Amos, Jedyne konieczne/ Unum necessarium, Wrocław 1996, translated from Latin by Joanna Sachse, introduction by Marek Magdziak and Joanna Sachse.

Komeński Jan Amos, Panegiryk Karolowi Gustawowi, Bezkrwawemu zwycięzcy Sarmacji, In: A. Konior (ed.), Jan Amos Komeński i bracia czescy w 380. Rocznicę przybycia do Leszna (1628-2008), Leszno 2009.

Komeński Jan Amos, Świat w obrazach rzeczy dostępnych zmysłom - Introduction and translation by Adam Fijałkowski, Warsaw 2015.

Komeński Jan Amos, Wielka dydaktyka, Introduction and note by B. Suchodolski, Wrocław 1956, p. XCVIII.

Konior Alojzy (ed.), Jan Amos Komeński i bracia czescy w 380. rocznicę przybycia do Leszna (1628-2008), State School of Higher Vocational Education in Leszno, Leszno 2009.

Konior Alojzy, Kalendarium z życia i twórczości J.A. Komeńskiego, In: „Przyjaciel Ludu", No. 2-3 / 1991.

Korthaase Werner, Wiele ze swoich najważniejszych dzieł napisał Komeński w Polsce, In: B. Sitarska, R. Mnich (eds.), Jan Amos Komeński a kultura epoki baroku, „Studia Comeniana Sedlcensia”, vol. 1, Siedlce 2007, p. 195-225.

Kupisiewicz Czesław, Szkice z dziejów dydaktyki, Cracow 2010.

Matysiuk Renata, Bezpieczeństwo człowieka jako wartość ponadczasowa, In: B. Sitarska (ed.), Jan Amos Komeński - współczesne interpretacje i reinterpretacje jego twórczości, "Siedlce Comeniological Research Bulletin, pedagogy series", vol. 3, Siedlce 2016, p. 103-114. 
Matysiuk Renata, Prawo do nauki w ujęciu Jana Amosa Komeńskiego, In: B. Sitarska (ed.) Współczesne recepcje Jana Amosa Komeńskiego, "Siedlce Comeniological Research Bulletin, pedagogy series", vol 4, Siedlce 2017, p. $127-140$.

Muszyński Heliodor, Komeńskiego koncepcja szkoły, In: B. Sitarska (ed.), Jan Amos Komeński - jego pedagogika i filozofia, "Siedlce Comeniological Research Bulletin, pedagogy series", vol. 2, Siedlce 2015, p. 101-128.

Muszyński Heliodor, Metodologiczne podstawy twórczości Jana Amosa Komeńskiego, In: B. Sitarska (ed.), Jan Amos Komeński i jego poglądy na edukację,"Siedlce Comeniological Research Bulletin, pedagogy series", vol. 1, Siedlce 2014, p. 93-118.

Natora Halina, Jan Amos Komeński - prekursor pedagogiki specjalnej, In: B. Sitarska (ed.), O Janie Amosie Komeńskim i jego poglądach na edukację, "Siedlce Comeniological Research Bulletin, pedagogy series", vol. 1, Siedlce 2014, p. 239-248.

Osadchenko Inna, Psychodidactic ideas of J.A. Comenius: from history to the present/ Психодидактичні ідеї Я.А.Коменського: від історії до сьогоденн, In: B. Sitarska (ed.) Współczesne recepcje Jana Amosa Komeńskiego, "Siedlce Comeniological Research Bulletin, pedagogy series", vol. 4, Siedlce 2017, p. 207-226.

Piaget Jean, Dokąd zmierza edukacja, Warsaw 1948.

Piaget Jean, Jan Amos Komeński (1592-1670), In: Cz. Kupisiewicz, I. Wojnar (eds.): Myśliciele o wychowaniu, vol. 1, Warsaw 1996.

Ploch Leszek, Edukacja do działań twórczych osób z niepetnosprawnościq, In: B. Sitarska, (ed.), Jan Amos Komeński- jego pedagogika i filozofia, "Siedlce Comeniological Research Bulletin, pedagogy series", vol. 2, Siedlce 2015, p. 165-190.

Ploch Leszek, Dar wartości ducha w biegu życia uczniów z niepełnosprawnościq $w$ interpretacji idei Jana Amosa Komeńskiego, In: B. Sitarska (ed.), Współczesne recepcje Jana Amosa Komeńskiego, "Siedlce Comeniological Research Bulletin, pedagogy series", vol. 4, Siedlce 2017, p. 83-104.

Podsiadły Adam, Jan Amos Komeński jako obywatel Leszna, In: B. Sitarska (ed.), Jan Amos Komeński - jego pedagogika i filozofia, "Siedlce Comeniological Research Bulletin, pedagogy series", vol. 2, Siedlce 2015, p. 237$-246$.

Pogoda-Kołodziejak Adriana, Studia Jana Amosa Komeńskiego w Niemczech, In: B. Sitarska (ed.) Jan Amos Komeński - jego pedagogika i filozofia, "Siedlce Comeniological Research Bulletin, pedagogy series", vol. 2, Siedlce 2015, p. 225-226.

Richter Manfred, Johann Amos Comenius und das Colloquium Charitativum von Thorn 1645. Ein Beitrag zum Ökumenismus, Siedlce 2013. 
Sebastian Schmidt, Glaube - Herrschaft - Disziplin: Konfessionalisierung und Alltagskultur in den Ämtern Siegen und Dillenburg (1538-1683), Paderborn 2005.

Sitarska Barbara (ed.) Jan Amos Komeński - jego pedagogika I filozofia / John Amos Comenius - his education science and philosophy/ Johann Amos Comenius - seine Pädagogik und Philosophie, "Siedlce Comeniological Research Bulletin, pedagogy series", vol. 2, Siedlce 2015.

Sitarska Barbara (ed.), Jan Amos Komeński - współczesne interpretacje i reinterpretacje jego twórczości, "Siedlce Comeniological Research Bulletin, pedagogy series", vol. 3, Siedlce 2016.

Sitarska Barbara, Knowledge in any place and at any time - the motto of contemporary educational research, In: Modern approaches in social and educational research/ Nowoczesne podejścia $w$ badaniach humanistycznych i pedagogicznych, edited by J.C. McDermott, B. Kožuh, Education Department, Antioch University Los Angeles, USA, Faculty of Education, University of Primorska, Slovenia, A.F. Modrzewski Cracow University, Los Angeles 2016, p. 251-272.

Sitarska Barbara, University Teacher as an Investigator of His Own Educational Practice, In: The Practical Science of Society, edited by: B. Kožuh, R. Kahn, A. Kozłowska, University of North Dakota (USA), Grand Forks, 2008, p. 185-198.

Sitarska Barbara, Droga człowieka do poznawania siebie w ujęciu Jana Amosa Komeńskiego, In: B. Sitarska (ed.), Jan Amos Komeński - jego pedagogika i filozofia, "Siedlce Comeniological Research Bulletin, pedagogy series", vol. 2, Siedlce 2015, p. 145-156.

Sitarska Barbara, Freiheit, Verantwortung und Identität als Schlüsselkonzepte zum Verständnis des Lebens, der Arbeit und des Werkes des Johann Amos Comenius?/ Wolność, odpowiedzialność i tożsamość jako kluczowy projekt (zamysł) do zrozumienia życia, pracy i dzieła Komeńskiego, In: Goris V., Meyer, M.A., Urbánek V. (Hrsg.), Gewalt się ferne den Dingen! Contemporary Perspectiveson the Works of John Amos Comenius, Springer VS Publishing, Wiesbaden 2016, p. 95-105.

Sitarska Barbara, Johann Amos Comenius als Vorkämpfr der Idee der lebenslangen Bildung, In: B. Sitarska, R. Mnich, M. Richter (eds.), Werner Korthaase - badacz Jana Amos Komeńskiego, "Studia Comeniana Sedlcensia", vol. 2, Siedlce 2009, p. 271-280.

Sitarska Barbara, Mnich Roman (eds), Jan Amos Komeński a kultura epoki baroku, „Studia Comeniana Sedlcensia”, vol. 1, Siedlce, 2007.

Sitarska Barbara, Mnich Roman, Richter Manfred (eds.), Werner Korthaase badacz Jana Amosa Komeńskiego, „Studia Comeniana Sedlcensia”, vol. 2, Siedlce 2009. 
Sitarska Barbara, O Janie Amosie Komeńskim i jego poglądach na edukacje/ John Amos Comenius and his views of education / Über Johann Amos Comenius und seine Ansichten zur Bildung, "Siedlce Comeniological Research Bulletin, pedagogy series", Siedlce 2014.

Sitarska Barbara, O Janie Amosie Komeńskim i poczq̨tkach komeniologii (in Polish, English and German), In: B. Sitarska (ed.) Jan Amos Komeński jego pedagogika i filozofia, "Siedlce Comeniological Research Bulletin, pedagogy series", vol. 2, Siedlce 2015, 23-90.

Sitarska Barbara, O Janie Amosie Komeńskim, In: Jan Amos Komeński, Świat w obrazach opisany / Świat w obrazach opisany po polsku w dziele Jana Amosa Komeńskiego wydanym w Brzegu w 1667 roku, Perception of part of the book by Jacek Strzałkowski to cemmemorate the 350th anniversary, Brzeg 2017.

Sitarska Barbara, The Political Dimension of the Pedagogy of John Amos Comenius, In: "Studia Comeniana et Historica", no. 87-88, edited by Pavel Floss, Martin Steiner, Marta Bečková, Jiři Beneš, Karel Floss, Musaeum Comenii Hunno Brodense XXXXII, Comenius Museum in Uhersky Brod, 2012, p. 27-49.

Sitarska Barbara, The role of media in the learning process at a higher education institution on the 350th anniversary of Comenius' collection of works Opera didactica omnia, In: Odkaz Jana Amose Komenského kultuře vzdělávání, John Amos Comenius Pedagogical Museum, edited by Svatova Chocholová, Markěta Pánková, Martin Steiner, Academia, Prague 2009, p. 744-751.

Sitarska Barbara, Zamiast Wprowadzenia. O recepcji własnej Jana Amosa Komeńskiego i autorów "Siedleckich Zeszytów Komeniologicznych, seria pedagogika", In: B. Sitarska (ed.), Współczesne recepcje Jana Amosa Komeńskiego, "Siedlce Comeniological Research Bulletin, pedagogy series", vol. 4, Siedlce 2017, p. 13-53.

Sitarska Barbara, Ян Амос Коменский: путь человека к познанию самого себя как путь к гармонии в мире хаоса, Man's way oflearning about himself as a way to reach harmony in the world of chaos according toJohn Amos Comenius, In: „Высокий лад, глубокий мир": между реализмом и постмодернизмом, edited by Ewa Kozak, Aldona Borkowska, Barbara Stelingowska, Joanna Tkaczyk, Franciszek Karpiński, Institute of Regional Culture and Literary Research. Association, Polish Studies and Neophilology Institute of Siedlce University of Natural Sciences and Humanities, Matej Bel University, Banska Bystrica, 2018, p. 199-212. 
Sitarska Barbara: Dlaczego Jan Amos Komeński wciąż żyje wśród nas?, In: B. Sitarska, R. Mnich (eds.): Jan Amos Komeński w kontekście kultury i historii europejskiej XVII wieku, „Studia Comeniana Sedlcensia', vol. 3, Siedlce 2010, p. 149-160.

Sroczyński Wojciech, Jan Amos Komeński - teolog, filozof, pedagog, In: B. Sitarska (ed.), Jan Amos Komeński - współczesne interpretacje i reinterpretacje jego twórczości, "Siedlce Comeniological Research Bulletin, pedagogy series", vol. 3, Siedlce 2016, p. 35-52.

Strzałkowski Jacek (ed.), Jan Amos Komeński, Świat w obrazach opisany / Świat w obrazach opisany po polsku w dziele Jana Amosa Komeńskiego wydanym $w$ Brzegu $w 1667$ roku, Perception of part of the book by Jacek Strzałkowski to cemmemorate the 350th anniversary, Brzeg 2017.

Suchodolski Bogdan, Komeński, Warsaw 1979.

Sztobryn Sławomir, Pedagogika Nowego Wychowania, In: Kwieciński Z., Śliwerski B. (eds.), Pedagogika. Podręcznik akademicki, vol. 1, Warsaw 2003.

Sztobryn Sławomir, Polska XX-wieczna recepcja pedagogiki Jana Amosa Komeńskiego, In: B. Sitarska (ed.) Współczesne recepcje Jana Amosa Komeńskiego, "Siedlce Comeniological Research Bulletin, pedagogy series", vol. 4, Siedlce 2017, p. 57-72.

Sztobryn Sławomir, Wprowadzenie do pansoficznych podstaw pedagogiki Jana Amosa Komeńskiego, In: B. Sitarska (ed.), Jan Amos Komeński - współczesne interpretacje i reinterpretacje jego twórczości, "Siedlce Comeniological Research Bulletin, pedagogy series", vol. 3, Siedlce 2016, p. 25-34.

Szymańska Kamila, Jan Amos Komeński i bracia czescy w działalności Muzeum Okręgowego w Lesznie, In: B. Sitarska (ed.) Współczesne recepcje Jana Amosa Komeńskiego, "Siedlce Comeniological Research Bulletin, pedagogy series", vol. 4, Siedlce 2017, p. 141-146.

Szymańska Kamila: Kontakty zagraniczne Jana Amosa Komeńskiego (zarys problematyki), In: B. Sitarska (ed.) Jan Amos Komeński - jego pedagogika i filozofia, "Siedlce Comeniological Research Bulletin, pedagogy series", vol. 2, Siedlce 2015, p. 227-236.

Tyluś Urszula, Egalitaryzm w poglądach Jana Amosa Komeńskiego, In: B. Sitarska (ed.), O Janie Amosie Komeńskim i jego poglądach na edukację, "Siedlce Comeniological Research Bulletin, pedagogy series", vol. 1, Siedlce 2014, p. 141-148.

Vasoli Cezare, Encyklopedyzm w XVII wieku, Warsaw 1966. 
Wiśniewska Małgorzata, Recepcja edukacji obronnej w twórczości Jana Amosa Komeńskiego, In: B. Sitarska (ed.) Współczesne recepcje Jana Amosa Komeńskiego, "Siedlce Comeniological Research Bulletin, pedagogy series", vol. 4, Siedlce 2017, 147-154.

Żegnałek Kazimierz, Dydaktyka Jana Amosa Komeńskiego, In: B. Sitarska (ed.), O Janie Amosie Komeńskim i jego poglądach na edukację, "Siedlce Comeniological Research Bulletin, pedagogy series", vol. 1, Siedlce 2014, p. 63-92.

www.comenius.uph.edu.pl

ICI Journals Master List 